\title{
Comparative Studies of Small Purse Seiner in North Sulawesi, Indonesia
}

\author{
Heffry Veibert DIEN*, Nobuo KIMURA**, \\ Yasuzumi FUJIMORI ${ }^{* * *}$ and Ixchel Feibe MANDAGI ${ }^{* *}$
}

\begin{abstract}
A series measurement of coastal fishing boats (small purse seiners) has been made in North Sulawesi province, Indonesia. The goal of this study is to clarify the physical characteristics of the small purse seiners in North Sulawesi. First of all we examined the boat form of the purse seiners and practical conditions under fishing operations. Based on the data, the characteristics such coefficient of fineness and the boat's stability were calculated.

Typical fishing boats in Indonesia have conventional round hull shapes with a long bar keel. Purse seiners in North Sulawesi have different characteristics in every region, especially for principal dimensions and boat's designs.

The results of the analysis are as follows: the boat types are relatively slim around the hulls and have the round shape under water, stability values are relatively small, and the cluster based on the principal dimensions and the coefficient of fineness has been categorized into two groups and three classes.
\end{abstract}

Keywords: Small purse seiners, stability, North Sulawesi, Indonesia

\section{Introduction}

As the fishing productions of North Sulawesi are relatively little comparing to its resources, the effective fishing technology is very important to utilize the fisheries with rational and optimal standard. To develop the fisheries, the fishing boat is one of the important factors among other fishing units. In general, the fishing boats utilizing in capture fisheries is the most capital in the fishing business.

The accidents of fishing boat generally occur 1 2 times per year because of miss loading of catch or cargo etc. on boat deck under the bad condition of weather. Especially, from September to January, the fishermen sometimes encounter stormy weather with the wind speed of $4.7-12.5 \mathrm{~m} / \mathrm{s}$ and the wave height of $2.0-5.0 \mathrm{~m}$.

The hull designs of fishing boats in Indonesia are rather different from those in other countries. Typical fishing boats have conventional round hull shapes with a long bar keel ${ }^{(7)}$.

In North Sulawesi, the purse seiners operated in this area have different characteristics from other area on technical and economic aspects. Especially, the stability, principal dimensions, and boat's designs for every region in North Sulawesi have different characteristics. However, there is few report about the technical characteristic of purse seiners.

Therefore, the field experiments for the stability of small purse seiner were carried out to know the condition of stability of purse seiners used in North Sulawesi, Indonesia.

\section{Material and Methods}

\subsection{Data measurement}

In this study, twelve fishing boats of the small purse seiners in North Sulawesi were selected. As shown in Fig. 2, these fishing boats are operating at the sea around Bitung, Manado, and Molibagu. The hull of all the boats have conventional round hull shape with a long bar keel as shown in Fig. 1. In addition, the four boats were chosen from the twelve fishing boats to calculate the static and dynamic stability.

In general, manufacture of traditional fishing boats in North Sulawesi does not use a body plan, so that all boats used in this study were needed to measure ship form and to make molded plan, as follows:

a. Measurements covering the main dimension: $L$ (length overall), $B$ (moulded breadth), $D$ (depth), $L_{w l}$ (water line length), $d$ (draft) (Fig. 4).

b. Drawing hull design used a pantograph with the following procedures (Fig. 6):

1. The length of the ship is almost divided into eleven sections from the stern to the bow in accordance with the characteristics of the hull.

Student member: Graduate School of Fisheries Sciences, Hokkaido University (Hakodate, Minato-cho 3-1-1, 041-8611) heffry@fish.hokudai.ac.jp

** Member: Graduate School of Fisheries Sciences, Hokkaido University (Hakodate, Minato-cho 3-1-1, 041-8611)

*** Non-member: Graduate School of Fisheries Sciences, Hokkaido University (Hakodate, Minato-cho 3-1-1, 041-8611)

**** Non-member: Graduate School of Information Science and Technology, Hokkaido University (Sapporo, Kita-ku, North 14, West 9, 0600814) 
2. Utilization of the pantograph with scale $1: 5$ for drawing the hull in every section; the pantograph was clipped on the freeboard deck line and then the arm of the pantograph was pulled along the hull from the keel until the freeboard deck line.

Stability test by the moment system was conducted on the following procedures:

a) Keeping the ship under still coundition.

b) Measuring the ship breadth.

c) Place the clinometer at amidships.

d) Sand as the burden placed on the periphery at amidships of boats as shown in Fig. 5 . e) The angle on the clinometer indicates the inclination of the boat.

Method in this study was followed to the procedure presented by some researches ${ }^{(1,2)}$. The principal dimensions, coefficient of fineness and the boat's stability by using the moment system were calculated. The boat volume was estimated by the Simpson's rules as commonly used at naval architectural works ${ }^{(1,2,3,4,5)}$. In addition, the cluster analysis was done using the principal dimensions and the fineness coefficients to compare the characteristics of each area.

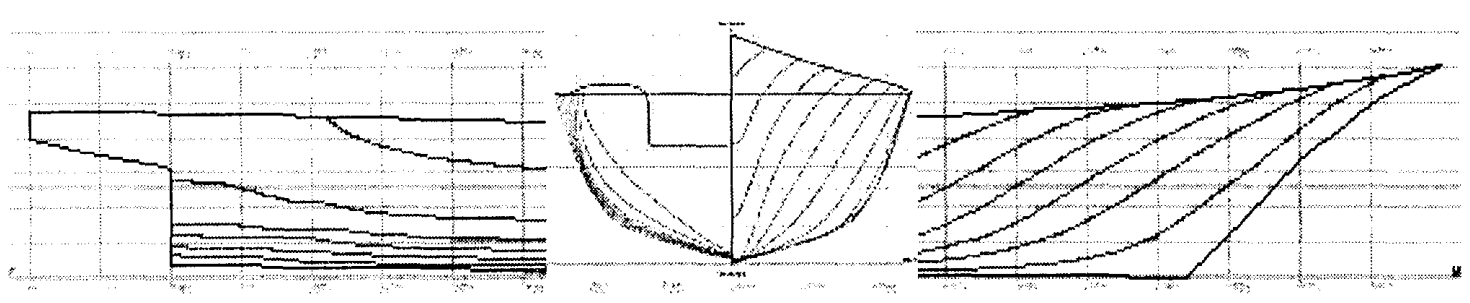

(a) Body plan of Bitung3

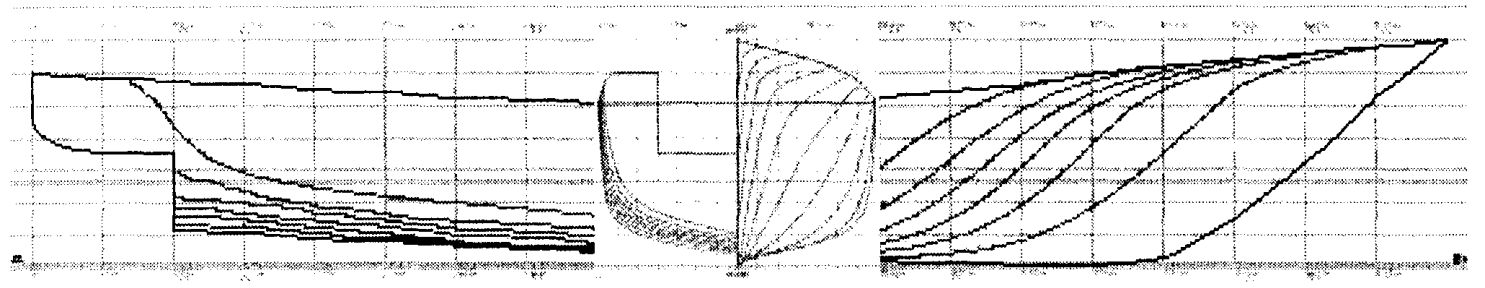

(b) Body plan of Jayakarya2

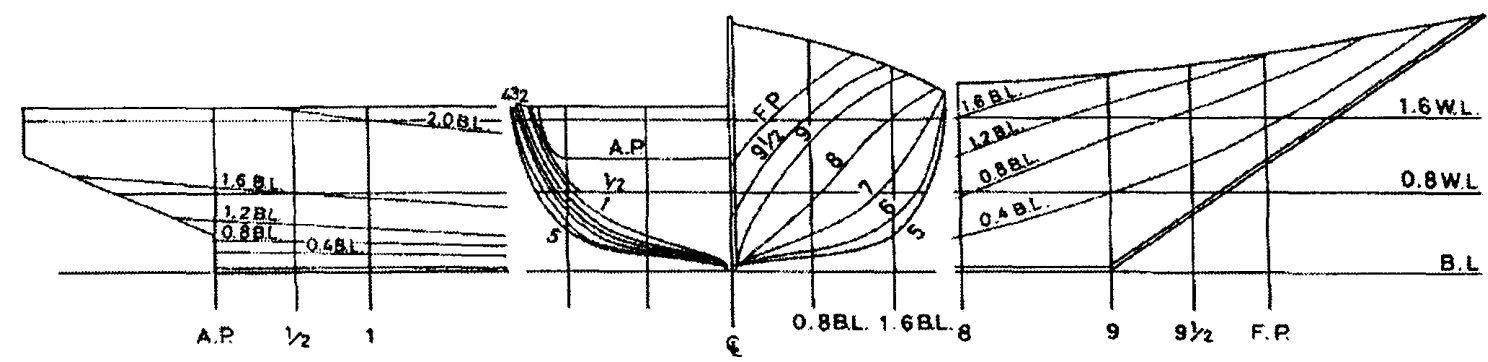

(c) Body plan of Bitung5

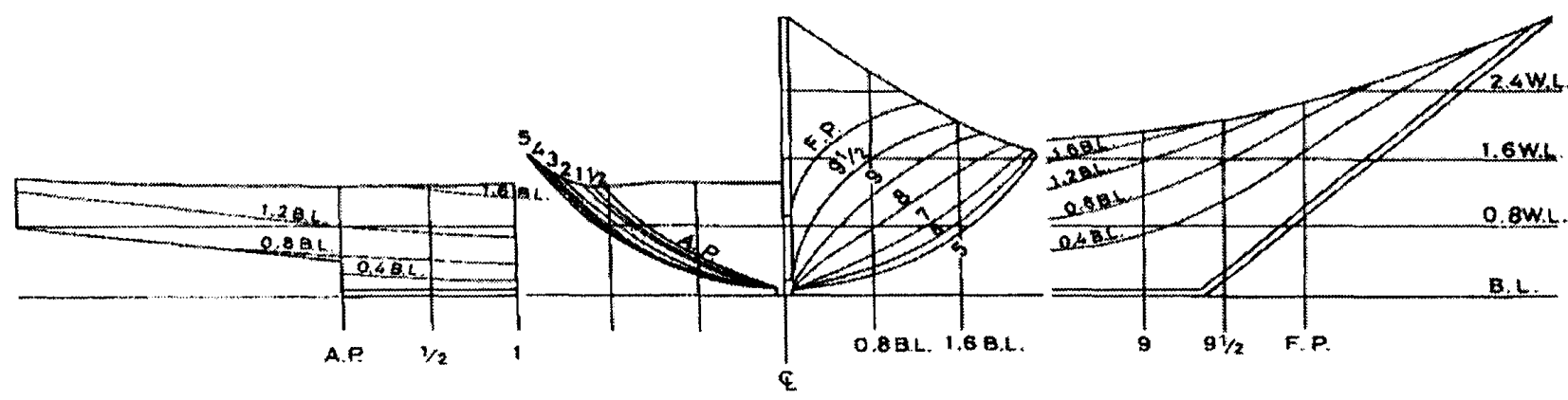

(d) Body plan of Bunaken

Fig. 1 Boat body plans of the purse seiners 


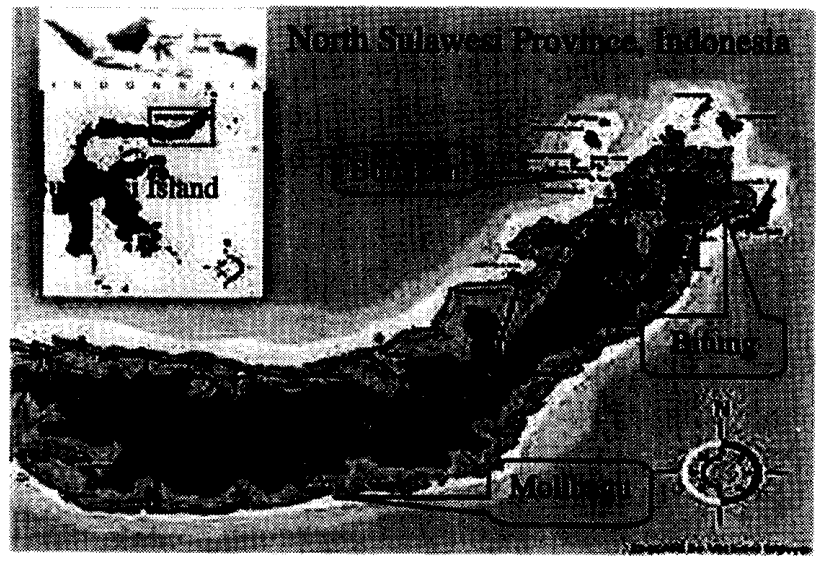

Fig. 2 Experimental field in North Sulawesi province

(a) Jayakarya2

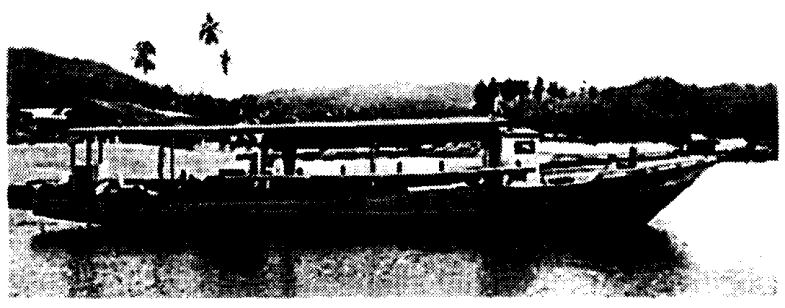

(c) Bunaken

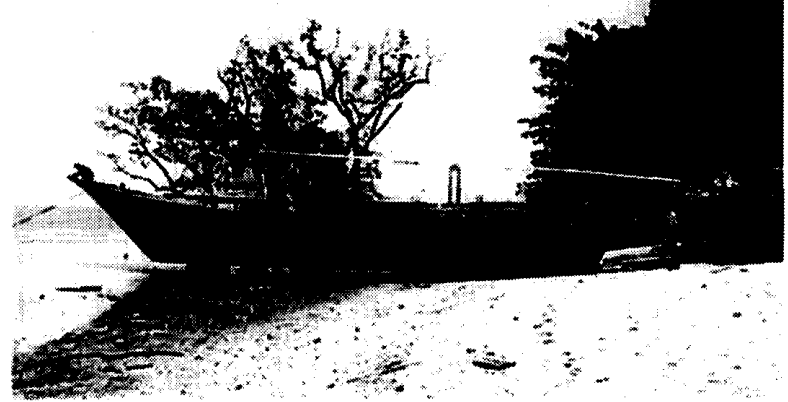

Table 1 Main dimensions of the purse seiners in North Sulawesi

\begin{tabular}{|l|c|c|c|c|c|c|c|c|}
\hline $\begin{array}{c}\text { Name of } \\
\text { boat }\end{array}$ & Location & $\begin{array}{c}L \\
(\mathrm{~m})\end{array}$ & $\begin{array}{c}B \\
(\mathrm{~m})\end{array}$ & $\begin{array}{c}D \\
(\mathrm{~m})\end{array}$ & $\begin{array}{c}d \\
(\mathrm{~m})\end{array}$ & $\begin{array}{c}\Delta \\
(\text { ton })\end{array}$ & $\begin{array}{c}K G \\
(\mathrm{~m})\end{array}$ & $\begin{array}{c}G M \\
(\mathrm{~m})\end{array}$ \\
\hline Tersanjung & Bitung & 15.85 & 2.90 & 1.32 & 0.607 & 5.722 & 0.921 & 0.455 \\
\hline Aldies & Bitung & 15.50 & 2.80 & 1.10 & 0.531 & 5.781 & 0.715 & 0.371 \\
\hline Bitung1 & Bitung & 14.72 & 3.81 & 1.44 & 0.864 & 13.012 & 2.206 & 0.273 \\
\hline Bitung2 & Bitung & 14.08 & 2.94 & 1.38 & 0.832 & 12.882 & 0.930 & 0.545 \\
\hline Bitung3 & Bitung & 10.72 & 2.27 & 0.99 & 0.584 & 4.910 & 0.910 & 0.263 \\
\hline Bitung4 & Bitung & 12.50 & 2.85 & 1.46 & 0.864 & 12.442 & 0.921 & 0.411 \\
\hline Bitung5 & Bitung & 19.20 & 4.26 & 1.74 & 0.576 & 12.571 & 1.556 & 1.033 \\
\hline Bunaken & Manado & 20.20 & 4.72 & 1.64 & 0.505 & 10.298 & 0.917 & 0.861 \\
\hline Jayakarya1 & Molibagu & 18.72 & 4.10 & 1.60 & 1.192 & 26.118 & 2.171 & 0.361 \\
\hline Jayakarya2 & Molibagu & 19.20 & 4.22 & 1.76 & 0.960 & 23.905 & 2.384 & 0.761 \\
\hline Jayakarya3 & Molibagu & 20.16 & 4.70 & 1.58 & 0.920 & 24.507 & 2.265 & 0.460 \\
\hline Balantungan & Molibagu & 19.84 & 4.35 & 1.81 & 1.050 & 32.656 & 2.075 & 0.349 \\
\hline
\end{tabular}
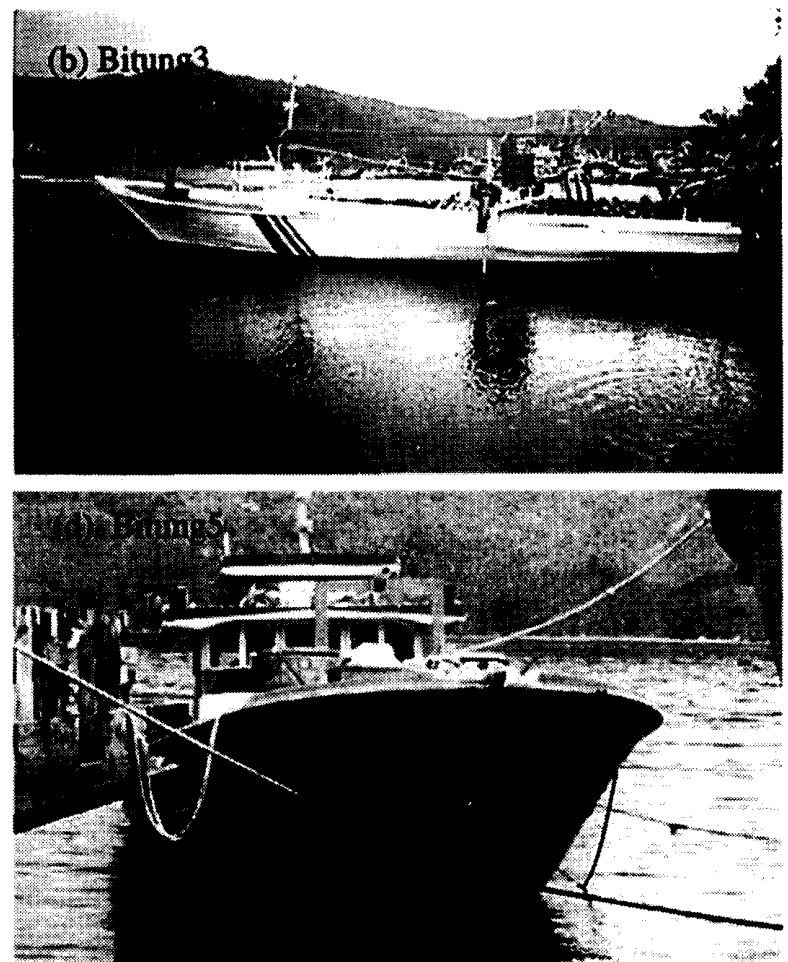

Fig. 3 Photos of the purse seiners

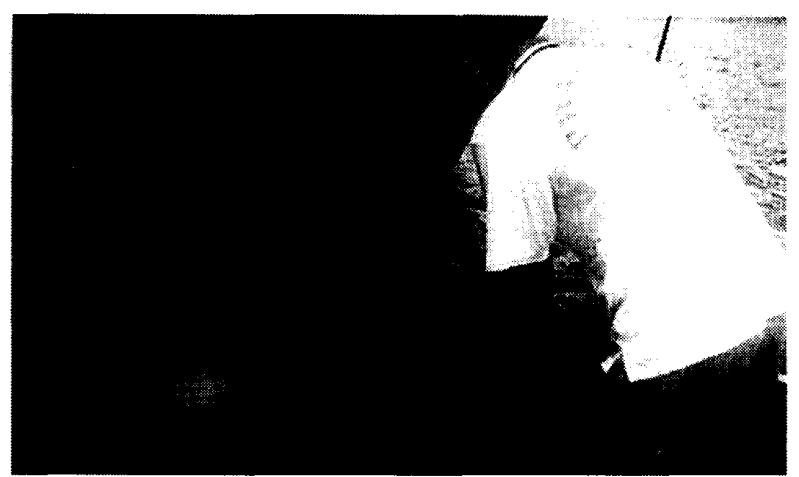

Fig. 4 Measurements covering the main dimension

\subsection{Boat stability ${ }^{(6,8)}$}

In this study, the metacentric height $G M$ and the righting lever $G Z$ are estimated by the moment system as follows :

$$
G M=\frac{w \cdot d}{(\Delta+w) \cdot \tan \emptyset}
$$

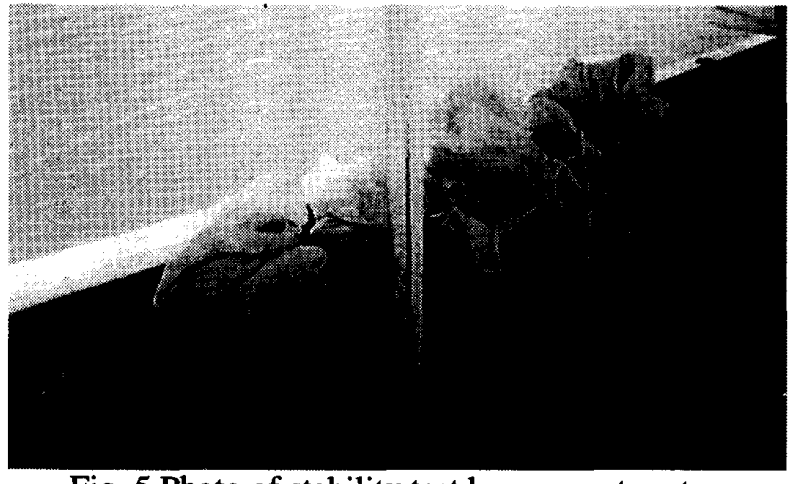

Fig. 5 Photo of stability test by moment system

$$
G Z=\sin \emptyset \cdot\left(G M+\frac{1}{2} B M \tan ^{2} \emptyset\right)
$$

Where, $w$ is weight

$d$ is distance of movement

$\Delta$ is boat's displacement

$\emptyset$ is the angle of inclination 
In addition, dynamic stability $D_{s t}$ is defined as follow:

$D_{s t}=\int_{0}^{\emptyset_{l}} \Delta \cdot G Z d \emptyset$

Where, $\emptyset_{1}$ is the angle of vanishing stability
A. Clamp
B. Drawing board
b. Drawing paper
C. Pencil
D. Pantograph arm
E. Boat

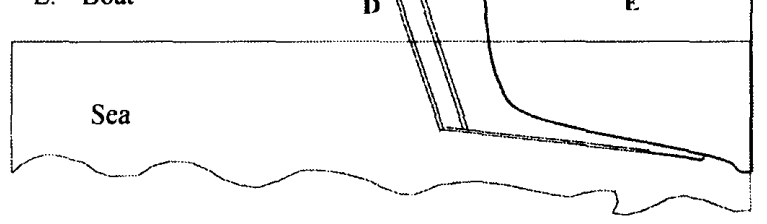

Fig. 6 Drawing hull design used pantograph system

\section{Result and Discussion}

3.1 Main dimensions and Coefficient of fineness

Calculation results of fineness coefficient are shown in Table 2. It is indicated that the purse seiners in North Sulawesi are slim around the hulls and have the rounded shape. Then, damping effect for rolling motion would be very weak. Such boat form is very effective for the speed of the boat. However, for the longitudinal strength, the hull structure is weak. This suggests the hull is easily broken when big waves hit.

Table 2 Comparison of the main particulars and Coefficients of fineness

\begin{tabular}{|l|c|c|c|c|c|c|c|}
\hline $\begin{array}{c}\text { Name of } \\
\text { boats }\end{array}$ & $L / B$ & $L / D$ & $B / D$ & $C b$ & $C p$ & $C m i d$ & $C w$ \\
\hline Tersanjung & 5.47 & 12.01 & 2.20 & 0.570 & 0.786 & 0.725 & 0.868 \\
\hline Aldies & 5.54 & 14.09 & 2.55 & 0.536 & 0.727 & 0.736 & 0.793 \\
\hline Bitung1 & 3.86 & 10.22 & 2.65 & 0.358 & 0.597 & 0.600 & 0.691 \\
\hline Bitung2 & 4.79 & 10.20 & 2.13 & 0.468 & 0.684 & 0.685 & 0.772 \\
\hline Bitung3 & 4.72 & 10.83 & 2.29 & 0.446 & 0.764 & 0.584 & 0.718 \\
\hline Bitung4 & 4.39 & 8.56 & 1.95 & 0.553 & 0.763 & 0.725 & 0.784 \\
\hline Bitung5 & 4.51 & 11.03 & 2.45 & 0.398 & 0.605 & 0.545 & 0.699 \\
\hline Bunaken & 4.28 & 12.32 & 2.88 & 0.398 & 0.685 & 0.356 & 0.720 \\
\hline Jayakarya1 & 4.57 & 11.70 & 2.56 & 0.430 & 0.670 & 0.641 & 0.686 \\
\hline Jayakarya2 & 4.55 & 10.91 & 2.40 & 0.523 & 0.653 & 0.801 & 0.822 \\
\hline Jayakarya3 & 4.29 & 12.76 & 2.97 & 0.395 & 0.639 & 0.617 & 0.687 \\
\hline Balantungan & 4.56 & 10.96 & 2.40 & 0.527 & 0.734 & 0.718 & 0.834 \\
\hline
\end{tabular}

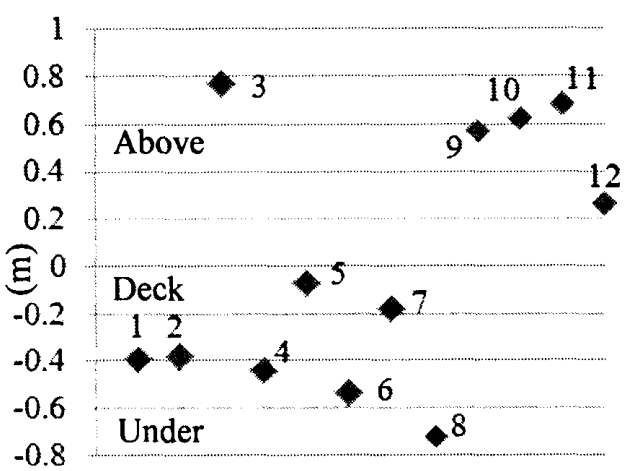

1. Tersanjung 2. Aldies 3. Bitung 1

4. Bitung2

5. Bitung3

6. Bitung 4

7. Bitung5

8. Bunaken

10. Jayakarya2

11. Jayakarya 3

12. Balantungan

$-0.8$

Fig. 7 Center of gravity position against the deck

\subsection{Center of gravity}

Table 1 presents the results of the calculation of $K G$. The results show that some boats have a center of gravity $(G)$ above the deck, as shown in Fig. 7.

In Fig. 7, there are five boats that center of gravity $(G)$ position is above the deck, and $G$ positions of the seven boats are under the deck. From field observations, there are five boats that have a house like the bridge on the deck, and there are two boats approaching the $G$ position close to the deck because the house is not too big, and $G$ position of other five boats without house are under the deck.

Fig. 8 shows that the length of the boats does not affect to the high value of $K G$. However, the value of $K G$ is determined by the existence of the house on the deck.

From these results, it is clear that the existence of houses on the deck will strongly affect the $G$ position.

\subsection{Stability}

Calculated results of static stability are shown in Table 3. The $G Z$ values for the four fishing boats show the regional characteristics. The $G Z$ values on every fishing boat are relatively small (Table 3 ).

Table $3 G Z_{\text {Max }}$ and Dynamical Stability

\begin{tabular}{|l|c|c|c|c|}
\hline \multirow{2}{*}{$\begin{array}{c}\text { Name of } \\
\text { boat }\end{array}$} & \multicolumn{2}{|c|}{ Static Stability } & \multicolumn{2}{c|}{ Dynamical stability } \\
\cline { 2 - 5 } & angle $\left(^{\circ}\right)$ & $G Z_{\text {Max }}$ & angle $\left(^{\circ}\right)$ & (m.rad) \\
\hline Jayakarya2 & 30.00 & 0.249 & 26.62 & 0.245 \\
\hline Bitung3 & 42.50 & 0.304 & 21.14 & 0.198 \\
\hline Bunaken & 45.00 & 0.684 & 21.41 & 0.349 \\
\hline Bitung5 & 42.50 & 0.450 & 31.36 & 0.385 \\
\hline
\end{tabular}

The broken lines in Fig. 9 indicate the heeling angle that the deck side is even to the sea level. As the deck of small purse seiners are not water tight construction, sea water will flood into the boat when heeling angle exceed this angle. The practical angles on the purse seiners used in this calculation are 21.14 deg for Bitung3, 26.62 deg for Jayakarya2, $31.36 \mathrm{deg}$ for Bitung5 and $21.41 \mathrm{deg}$ for Bunaken (Fig. 9), respectivelly.

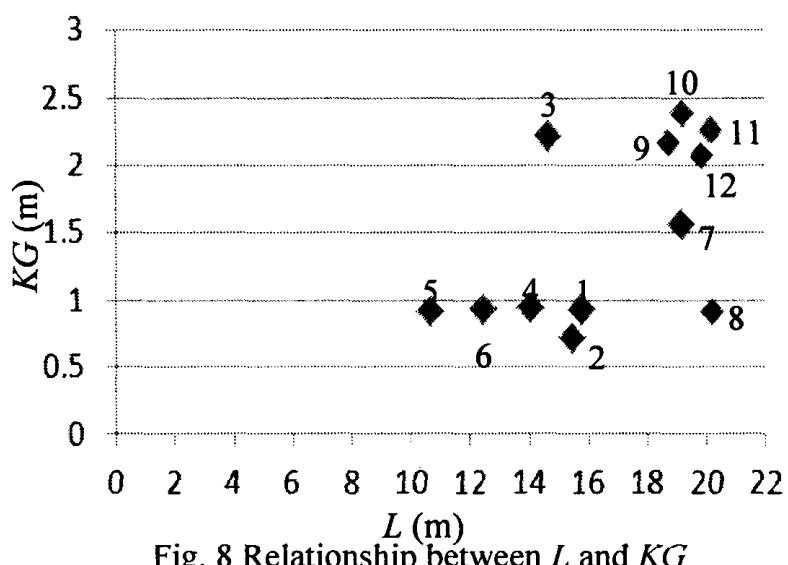

Fig. 8 Relationship between $L$ and $K G$ 


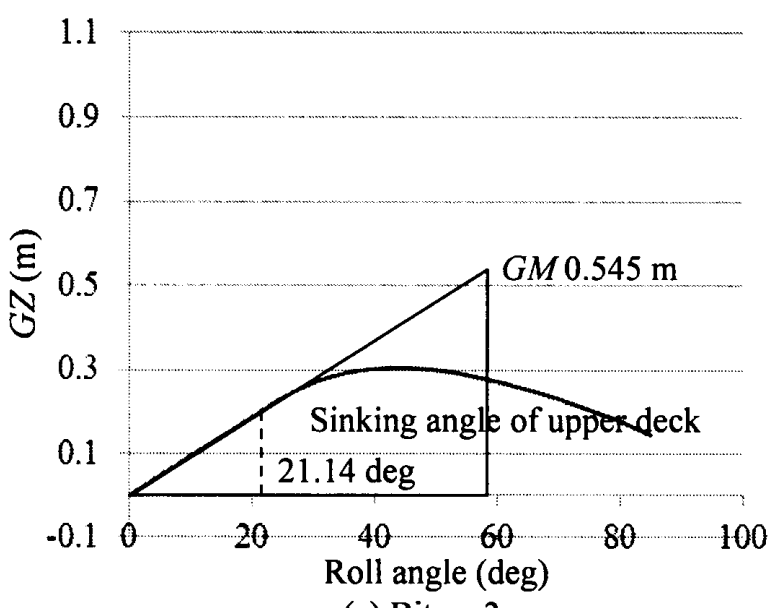

(a) Bitung3

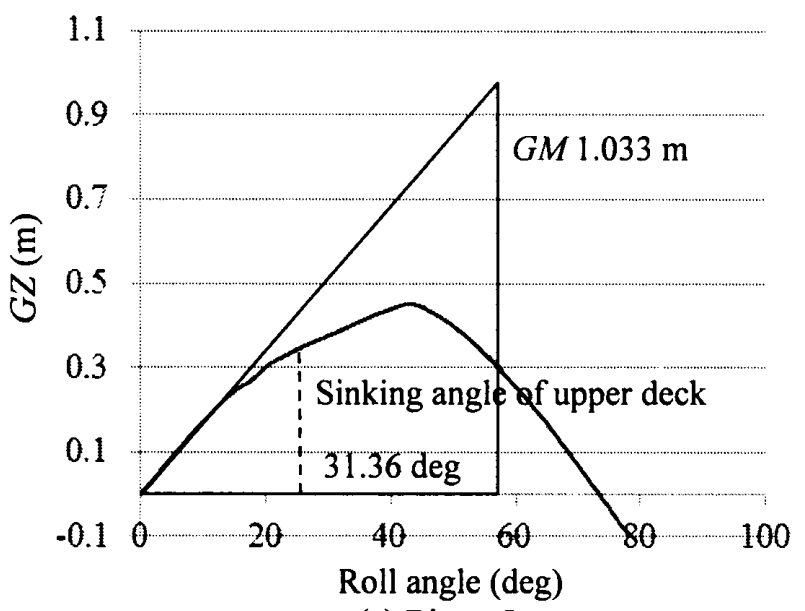

(c) Bitung5

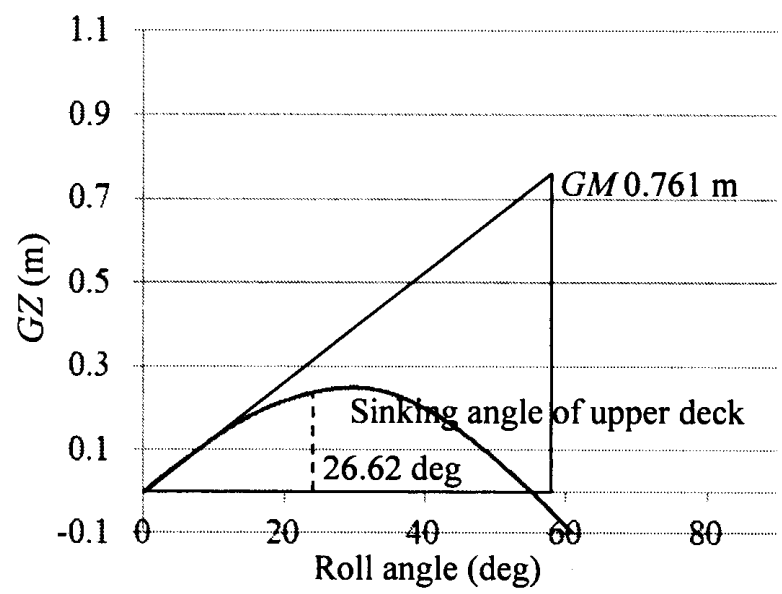

(b) Jayakarya2

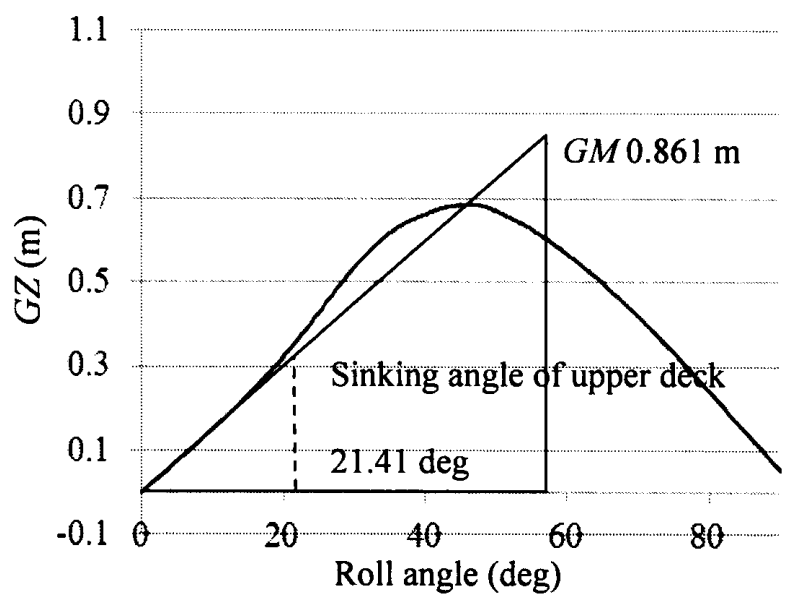

(d) Bunaken

Fig. 9 Stability curves of the purse seiners

\subsection{Cluster analysis}

To investigate regional characteristics of the small purse seiners, the cluster analysis was applied using the parameters, principal dimension, fineness coefficients and stability parameters, as shown in Fig. 10. The purse seiners in North Sulawesi used in this study are categorized into two groups and three classes.

The first group has only one class from the contents of the boat used in Molibagu. The second group consists of fishing boats used in Bitung and Bunaken.

Grouping is dominated by the displacement of boats shown in Fig. 11, the first group is 23.905 tons 32.656 tons and the second group is 4.910 tons 13.012 tons. Further, the second group is divided into two classes based on the length of the boat, in this case, the first class has a length of $10.72 \mathrm{~m}-15.50 \mathrm{~m}$ and the second class has a length of $15.85 \mathrm{~m}-20.20 \mathrm{~m}$.

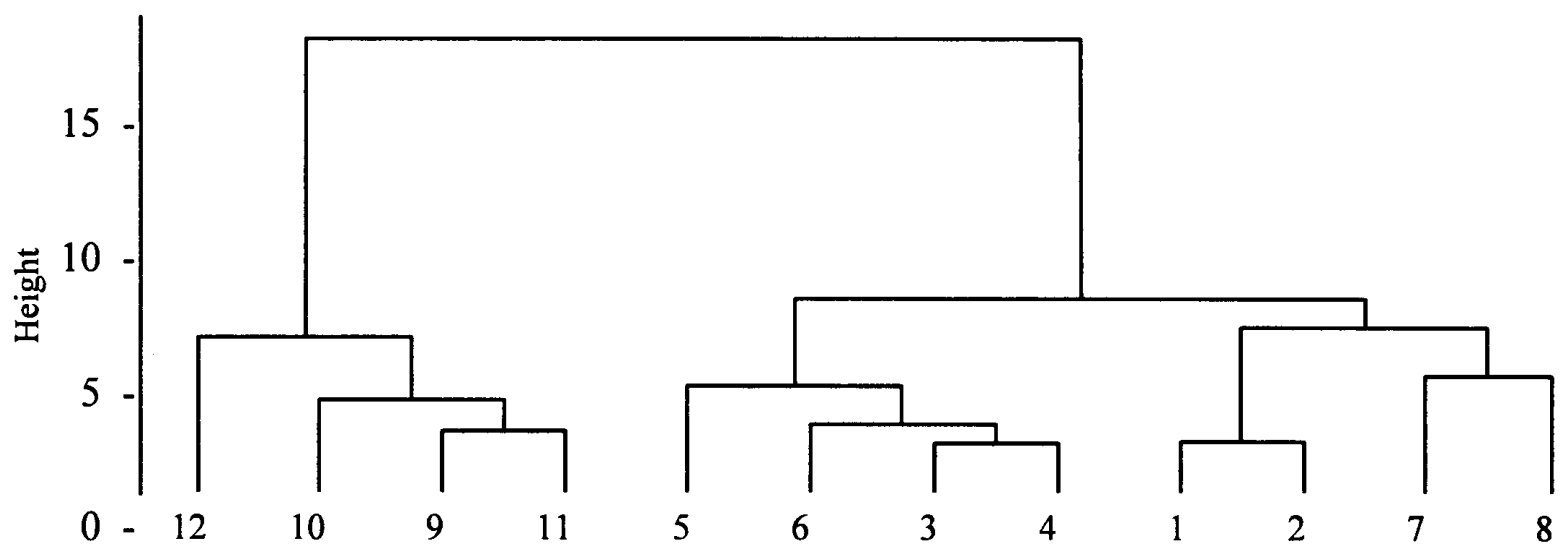

1. Tersanjung, 2. Aldies, 3. Bitung1, 4. Bitung2, 5. Bitung3, 6. Bitung4, 7. Bitung5,

8. Bunaken, 9. Jayakarya1, 10. Jayakarya2, 11. Jayakarya3, 12. Balantungan 


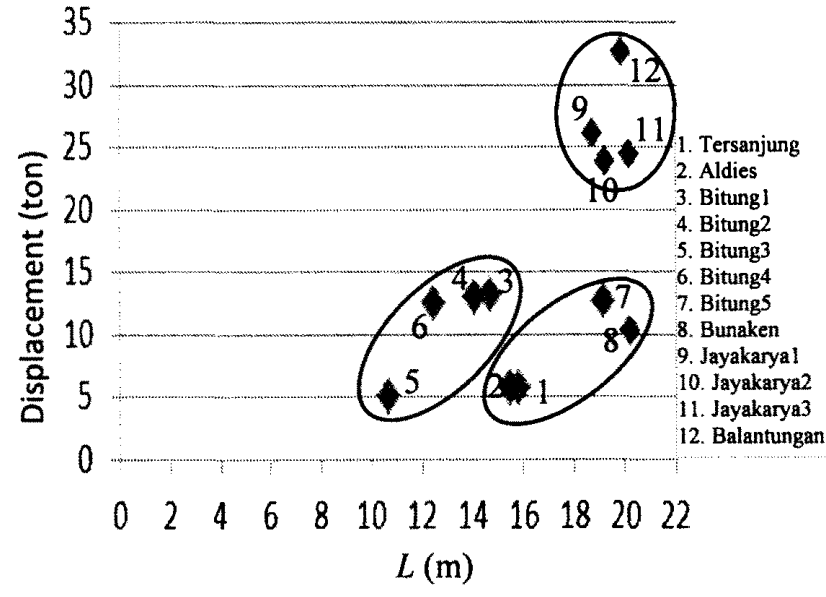

Fig. 11 Scatter diagram between displacements and $L$

\section{Conclusions}

Through the present analysis, we summarized as follows:

(1) The boat types in North Sulawesi are relatively slim around the hulls and have the round shape under water.

(2) As the $G Z$ values of purse seiners in North Sulawesi are relatively small, the boats will easily upset during fishing operations.

(3) Dynamic stability value is relatively small. Hence, seawater easily enters into the boat while sailing on rough sea, especially from September to January.

(4) The purse seiners in North Sulawesi are classified into two groups and three classes, from the cluster analysis.

As there are frequent accidents at sea during fishing operations, we show some suggestions:

(1) Fishermen should know the safe condition of weather to in engage fishing operations. If the weather condition is not suitable, fishing operations should be canceled.

(2) Fishermen should recognize how to arrange catch, cargo, etc. on the board so the boat will easily upset because of miss loading on the deck.

\section{Acknowledgement}

The authors expressed our gratitude to the boat owners used as samples, and the crews who helped us under researches. We also expressed special thanks to prof. Kawilarang W. A. Masengi.

\section{References}

(1) Hind J.A. : Stability and Trim of Fishing vessels, Fishing News Ltd., London, 120 p. 1967

(2) Attwood E.L., Pangelly H.S., and A.J. Sims. : Theoretical Naval Architecture, London, 375 p. 1953
(3) Muckle W. : Naval Architecture of Marine Engineering, News Butter Words, London, 407 p. 1978

(4) Comstock W. : Principles of Naval Architecture, The Society of Naval Architects and Marine engineering, USA, 872 p. 1967

(5) Ikeda M. : Theory and Design of Small Vessel, Kaibundo Publisher, Tokyo, 534 p. (in Japanese). 1978

(6) Baharuddin A., Katayama T. and Ikeda Y. : Roll Damping Characteristics of Fishing Boats with and without Drift Motion. Proceeding of $8^{\text {th }}$ International conference on the Stability of Ship and Ocean Vehicles. p.655-664, 2003

(7) Dien H.V., Masengi K.W.A., Labaro I.L., Mandagi I.F., Todingdatu R.M. : Comparative Studies of Small Purse Seiners (Pamo) at Bitung Municipality and Bolaang Uki Waters of North Sulawesi. Proceeding of The JSPS-DGHE International Symposium on Fisheries Science in Tropical Area. p. 113-115, 2000

(8) Takeuchi S., Kimura N., Fujimori Y. and Dien H.V. : Characteristics about Stability of $160 \mathrm{GT}$ Offshore Trawler under Fishing Operation in Following Sea. The Japan Society for Mathematical and Physical Fisheries Science Vol.7, p. 28-42, 2009

\section{Question and answer}

Seiichi Takeda (Tokyo University of marine sciences and Technology) :

Are there any agency recorded marine accidents in North Sulawesi, Indonesia?

Are the above-mentioned agencies conducting record about all of marine accident?

\section{Heffry Veibert Dien :}

Information about the marine accident can be obtained from:

1. Marine Police Department.

2. Department of marine and fisheries (especially for fishing boat).

Jun Kayono (Tokyo University of marine sciences and Technology):

Why are the boats types of North Sulawesi relatively slim?

Why are $G M$ values of purse seiner in North Sulawesi relatively small?

\section{Heffry Veibert Dien :}

Fishermen need high speed fishing boat so hull shape is slim. As the existence of house on the deck strongly affects the stability, the $G M$ value of the fishing boats with house is relatively small. 